\title{
Isolation and Characterization of the Chemical Constituents of Anacardium occidentale Cracked Bark
}

\author{
OE Fadeyi*, GA Olatunji and VA Ogundele
}

Department of Chemistry, University of Ilorin, P.M.B 1515, Ilorin, Nigeria

\begin{abstract}
The cracked bark of Anacardium occidentale were dried under ambient conditions, chopped into bits and the ethanolic extract of the cracked bark was obtained by cold extraction. Phytochemical screening was conducted to identify the types of secondary metabolites present using standard procedures. The profiles of the chemical constituents present were established using Thin Layer and Column Chromatography methods. Thus, pure chemical constituents were isolated from the cracked bark of Anacardium occidentale. The isolated compounds were characterized using FT-IR and their structures determined using data obtained from GC-MS spectrum.
\end{abstract}

Keywords: Anacardium occidentale; Ethanolic; Cracked bark; Phytochemical; Isolated; Characterized

\section{Introduction}

Cashew (Anacardium occidentale) is a tree that grows up to $15 \mathrm{~m}$ in height with thick tortuous trunk and woody branches. It belongs to the family anacardiaceae, native to Brazil and it is distributed throughout tropical countries such as Nigeria, Kenya, Tanzania, Mozambique [1,2]. Anacardium occidentale is commonly called cashew in English and in the major Nigerian languages: Hausa, Ibo and Yoruba, it is called 'Kashu', 'Okpokpo' and 'Kaju' respectively. The cashew tree produces many products. The bark, leaves and shell oil of $A$. occidentale have important medicinal values and industrial applications in the plastic and resin industries based on its phenol content. The nut has international appeal and high market value as a food source, especially in the beverage industry [3].

A. occidentale is a multipurpose tree whose leaves, stems and bark extracts have been used extensively for the treatment of diarrhea, dysentery and colonic pain [4]. There are reports that it possesses antidiabetic, anti-inflammatory, antimicrobial and analgesic properties $[4,5]$. The antimicrobial activity of ethanolic extract of $A$. occidentale leaves was attributed to 2-hydroxy-6-pentadecylbenzoic acid [1] and other compounds such as tatrols and tannins which are some of the chemical constituents identified in the ethanolic extract [6].<smiles>CCCCCCCCCCCCCCCc1cccc(O)c1C(=O)O</smiles>

Phytochemical analysis of $A$. occidentale reveals a rich variety of secondary metabolites [1]. The ethanolic extract of A. occidentale $\mathrm{L}$. nuts contains various phytochemical compounds such as triterpenoids, phenolics and volatile oils. Ethyl acetate extract exhibited a different combination of phytochemicals: phenolics, volatile oils, xanthoprotein and carbohydrates [1]. Acetone extract contained compounds like triterpenoids, phenolics, volatile oils, flavonoids, xanthoprotein and carbohydrates [1,7].

Several studies have been carried out to isolate natural products from various parts of A. occcidentale. 2-hydroxy-6-pentadecylbenzoic acid [1] and 2,6-dihydroxybenzoic acid [2] have been isolated from the cashew apple (ref. [8]). Other compounds isolated include myricetin [3], quercetin [4], kaempferol [5], rhamnetin [6] (ref. [9]), cyaniding [7], peonidin [8] and delphinidin [9] were also isolated [2]. 2-hydroxy6-pentadecylbenzoic acid [1], cardanol [10] and salicyclic acid [11] were isolated from the hydro-ethanolic extract of A. occidentale nuts [10].<smiles>O=C(O)c1c(O)cccc1O</smiles>

2,6-dihydroxybenzoic acid [2]

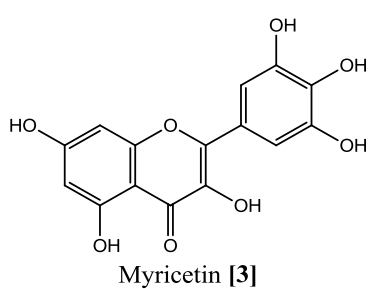<smiles>O=c1c(O)c(-c2ccc(O)c(O)c2)oc2cc(O)cc(O)c12</smiles>

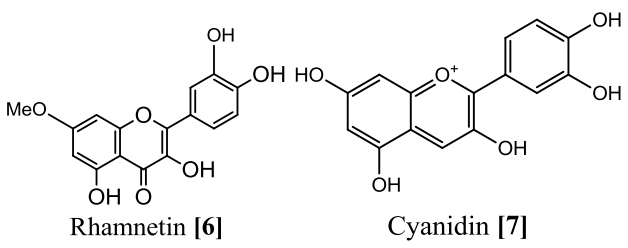<smiles></smiles><smiles>Oc1cc2c(O)c(O)c(O)cc2[o+]c1-c1cc(O)c(O)c(O)c1</smiles>

Delphinidin [9]

Also isolated from the ethanolic extract of $A$. occidentale flower were ethyl gallate [12], hyperoside (quercetin 3-galactoside) [13]. And from the ethanolic extract of the tender leaves, $\beta$-sitosterol [14] was isolated [11].

*Corresponding author: O. E. Fadeyi, Department of Chemistry, University of llorin P.M.B 1515, Ilorin, Nigeria, Tel: 2348062667993; E-mail: olaolufadeyi@gmail.com

Received September 14, 2015; Accepted September 28, 2015; Published September 30, 2015

Citation: Fadeyi OE, Olatunji GA, Ogundele VA (2015) Isolation and Characterization of the Chemical Constituents of Anacardium occidentale Cracked Bark. Nat Prod Chem Res 3: 192. doi:10.4172/2329-6836.1000192

Copyright: $\odot 2015$ Fadeyi OE, et al. This is an open-access article distributed under the terms of the Creative Commons Attribution License, which permits unrestricted use, distribution, and reproduction in any medium, provided the original author and source are credited. 


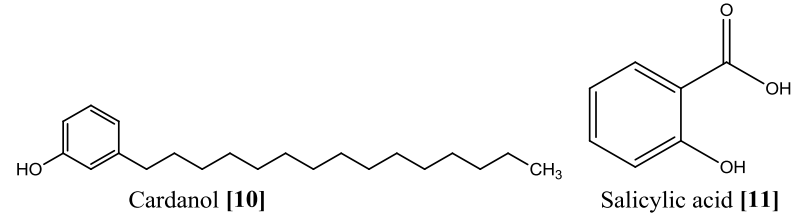

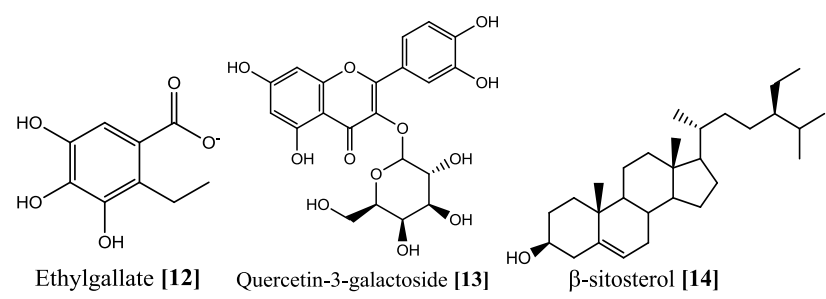

The research was carried out to study the chemical constituents of A. occidentale and discuss their relevance to the medicinal uses of the plant by isolation of the chemical compounds present as well as their characterization.

\section{Materials and Methods}

\section{Collection and identification of plant materials}

Anacardium occidentale cracked bark was collected from University of Ilorin Botanical Garden, Nigeria. The plant samples were collected from four different trees, identified and documented at the Herbarium of the Department of Plant Biology, University of Ilorin.

\section{Extract preparation}

The cracked stem bark was pulverized and dried under ambient conditions. 600 grams of the plant material was extracted with ethanol for 72 hours and the resultant crude extract obtained was filtered. The crude extract was concentrated under reduced pressure using a rotary evaporator to obtain a solvent-free ethanol extract.

\section{Phytochemical analysis}

Qualitative phytochemical screening was carried to determine the presence of alkaloids, saponins, phenolics, flavonoids, steroids and terpenoids using the standard literature procedure [12].

\section{Thin layer chromatography}

Thin layer chromatography of the cracked bark was carried out to identify the unique distinguishing chemical constituents present in the cracked bark. Commercial thin layer chromatographic plate (Merck, Germany) was used. The solvent used was dichloromethane. Thin Layer Chromatograms were viewed under the UV lamp at the long wavelength of $366 \mathrm{~nm}$.

\section{Column chromatography}

The crude extracts were fractionated using Si-gel column chromatography. n-hexane and dichloromethane were used as eluents (Eluent ratio; n-hexane/DCM 4:1 to n-hexane/DCM 1:3). Fractions obtained were collected in $50 \mathrm{~mL}$ flasks. Identical fractions were pooled based on their TLC profiles thus resulting in 5 combined fractions. Further purification using preparative thin layer chromatography was carried out on fractions that were impure.

\section{Preparative thin layer chromatography}

Self-coated preparative thin layer chromatography plates were used to isolate and purify the chemical components. The plates were coated with slurry of silica gel mixed with appropriate amount of binder (calcium sulphate) and activated at $103^{\circ} \mathrm{C}$ for $15 \mathrm{~min}$ in a drying oven.

\section{Spectroscopic analyses}

The isolates were characterized using data obtained from FourierTransform Infrared (FTIR) Spectroscopy and Gas ChromatographyMass Spectroscopy (GC-MS).

Infrared spectroscopy: The infrared spectroscopic analyses of the isolates were carried out so as to know the different functional groups present in the isolated compounds. The infrared spectra were recorded on Shimadzu 8400 s (Schimadzu Corporation, Kyoto Japan) Fourier Transform-Infrared (FT-IR) Spectrophotometry using $\mathrm{KBr}$ pellet.

GC-MS analysis: The analysis was done on Agilent 7890 A GC/ MS equipped with a Quadrupole Mass Spectra Detector and an Autosampler. GC-MS system settings are as follows; $200^{\circ} \mathrm{C}$, interfaced temperature, $250^{\circ} \mathrm{C}$, solvent cut time; $2.50 \mathrm{~min}$; relative detector mode, ACQ mode; Scan; start time - end time; $3.00 \mathrm{~min}-56.00 \mathrm{~min}$, event time, $0.50 \mathrm{sec}$; scan speed, 1428 .

\section{Results and Discussion}

\section{Phytochemical analysis}

The ethanolic extract of Anacardium occidentale cracked bark showed various phytochemicals like phenolics, flavonoids, triterpenoids and saponins. Alkaloids and saponins were not detected. This agrees with the results of Fazali et al. [13].

\section{Column chromatography of the cracked bark extract}

A total of seventy-one fractions were collected from the column chromatography fractionation of the cracked bark crude extract (Sigel). Combined fractions 29-39 was purified using PTLC.

\section{Infrared spectra of isolated compounds}

From the IR spectra of the isolated compounds, the bands observed are summarized in Table 1.

F29-29/Z2

The O-H stretching band at $3444 \mathrm{~cm}^{-1}$ is of an alcohol. The O-H can be said to be associated. The C-H stretching at $2929 \mathrm{~cm}^{-1}, 2854 \mathrm{~cm}^{-1}$ corresponds to that of an aliphatic $\mathrm{C}-\mathrm{H}$. The $\mathrm{C}-\mathrm{O}$ absorption peak for alcohol appeared at $1199 \mathrm{~cm}^{-1}$ while the $\mathrm{O}-\mathrm{H}$ bend occurred at 1219 $\mathrm{cm}^{-1}, 1265 \mathrm{~cm}^{-1}$ (Figure 1).

\section{F29-39/Z1}

The O-H stretching band at $3423 \mathrm{~cm}^{-1}$ is that of an alcohol. The C-H stretching at $2926 \mathrm{~cm}^{-1}, 2854 \mathrm{~cm}^{-1}$ corresponds to that of an aliphatic $\mathrm{C}-\mathrm{H}$. The C-O absorption peak for alcohol appeared at 1097, 1084 $\mathrm{cm}^{-1}$ while the $\mathrm{C}-\mathrm{H}$ bends occurred at $1421 \mathrm{~cm}^{-1}, 1442 \mathrm{~cm}^{-1}, 1479 \mathrm{~cm}^{-1}$ (Figure 2).

\begin{tabular}{|l|l|l|l|l|l|l|l|}
\hline Sample Code & $\begin{array}{l}\overline{\mathrm{v}} \\
\mathrm{O}-\mathrm{H} \\
\mathrm{cm}^{-1}\end{array}$ & $\begin{array}{l}\overline{\mathrm{U}} \text {-H } \\
\mathrm{cm}^{-1}\end{array}$ & $\begin{array}{l}\overline{\mathrm{v}} \mathrm{C}=\mathrm{O} \\
\mathrm{cm}^{-1}\end{array}$ & $\begin{array}{l}\overline{\mathrm{v}} \mathrm{C}=\mathrm{C} \\
\mathrm{cm}^{-1}\end{array}$ & $\begin{array}{l}\overline{\mathrm{v}} \\
\mathrm{C}-\mathrm{O} \\
\mathrm{cm}^{-1}\end{array}$ & $\begin{array}{l}\overline{\mathrm{v}} \mathrm{C}-\mathrm{H} \text { (bend) } \\
\mathrm{cm}^{-1}\end{array}$ & $\begin{array}{l}\overline{\mathrm{v}} \mathrm{O}-\mathrm{H} \text { (bend) } \\
\mathrm{cm}^{-1}\end{array}$ \\
\hline F29-39/Z2 & 3444 & $\begin{array}{l}2926, \\
2854\end{array}$ & - & - & 1199 & - & $\begin{array}{l}1265 \\
1219\end{array}$ \\
\hline F29-39/Z1 & 3423 & $\begin{array}{l}2926, \\
2854\end{array}$ & - & - & 1192 & 1479,1442 & \\
\hline
\end{tabular}

Table 1: FT-IR Spectral data of isolated compounds. 


\section{ФSHIMADZU}

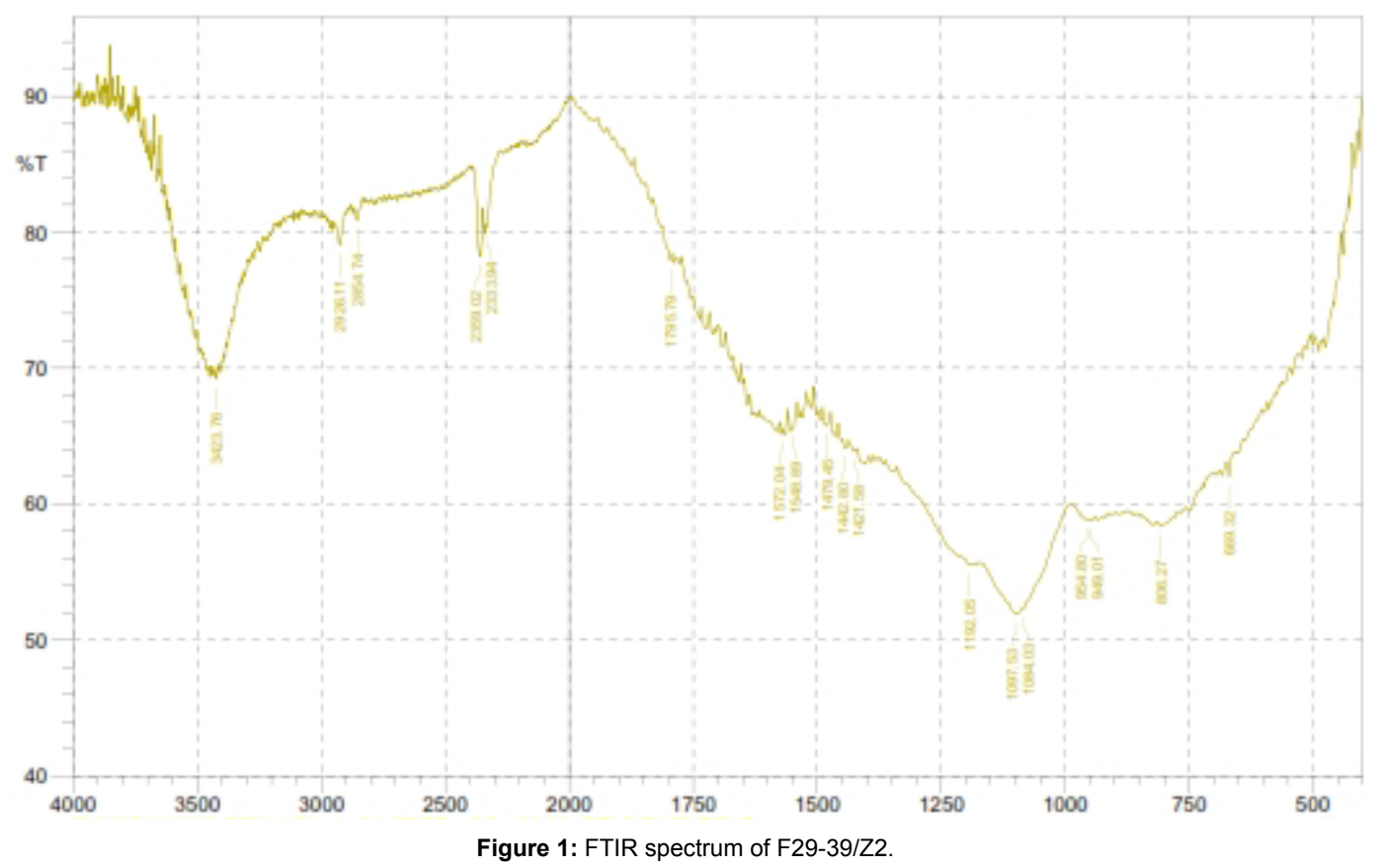

ФSHIMADZU

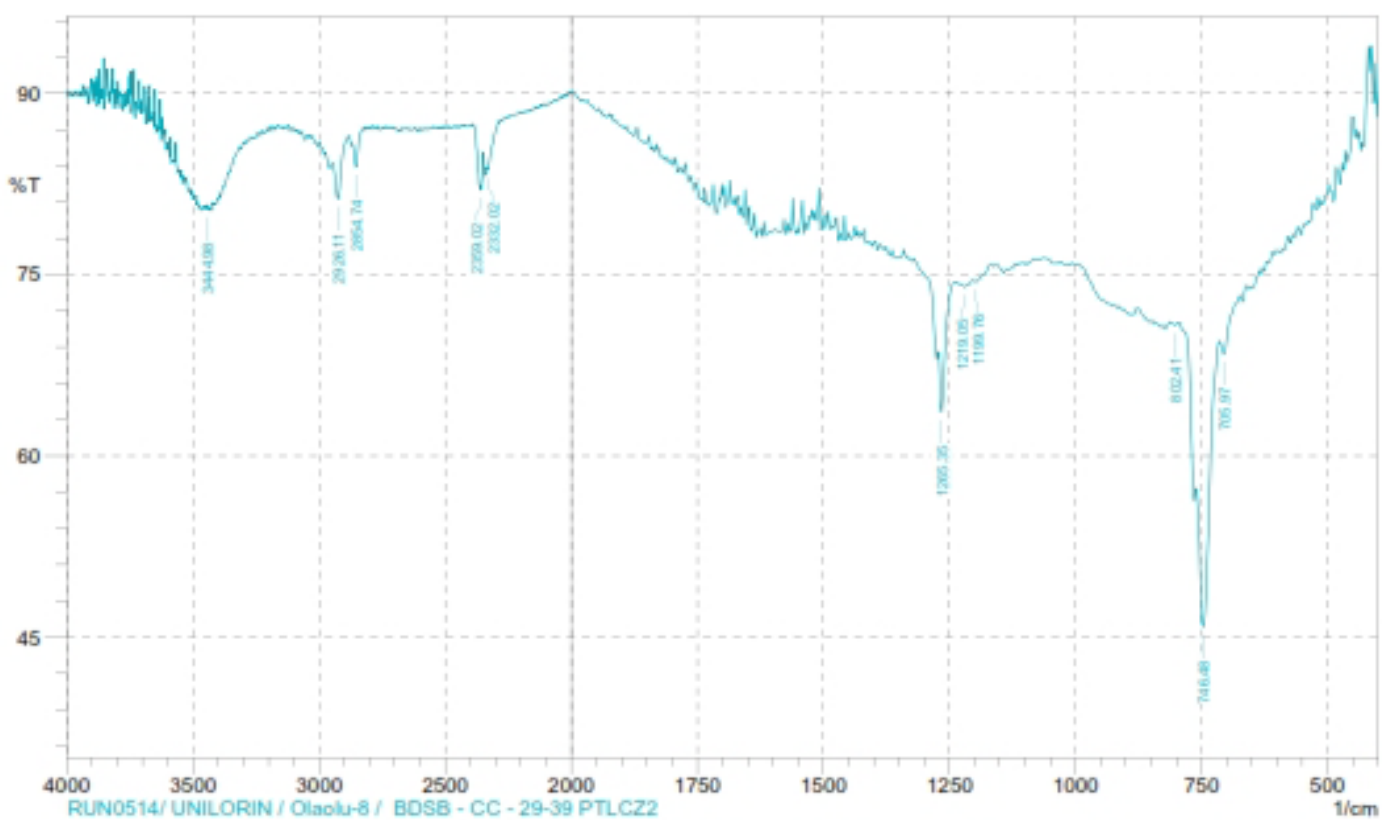

Figure 2: FTIR Spectrum of F29-39/Z1.

\begin{tabular}{|l|l|l|l|l|}
\hline S No & Name of Proposed Compound & Ret. Time & \% Composition & Mass spectra data \\
\hline 1. & n-hexadecanoic acid & 45.847 & 34.22 & $57,60,69,73,83,97,115,129,171,185,213,256$ \\
\hline 2. & 17-octadecynoic acid & 50.110 & 14.59 & $55,50,73,83,91,95,109,207$ \\
\hline 3. & Cyclohexanecarboxylic acid, decyl ester & 53.434 & 51.19 & $57,73,84,98,116,129,147,185,207,239,281$ \\
\hline
\end{tabular}

Table 2: GC-MS Analysis Result of F29-39/Z2. 

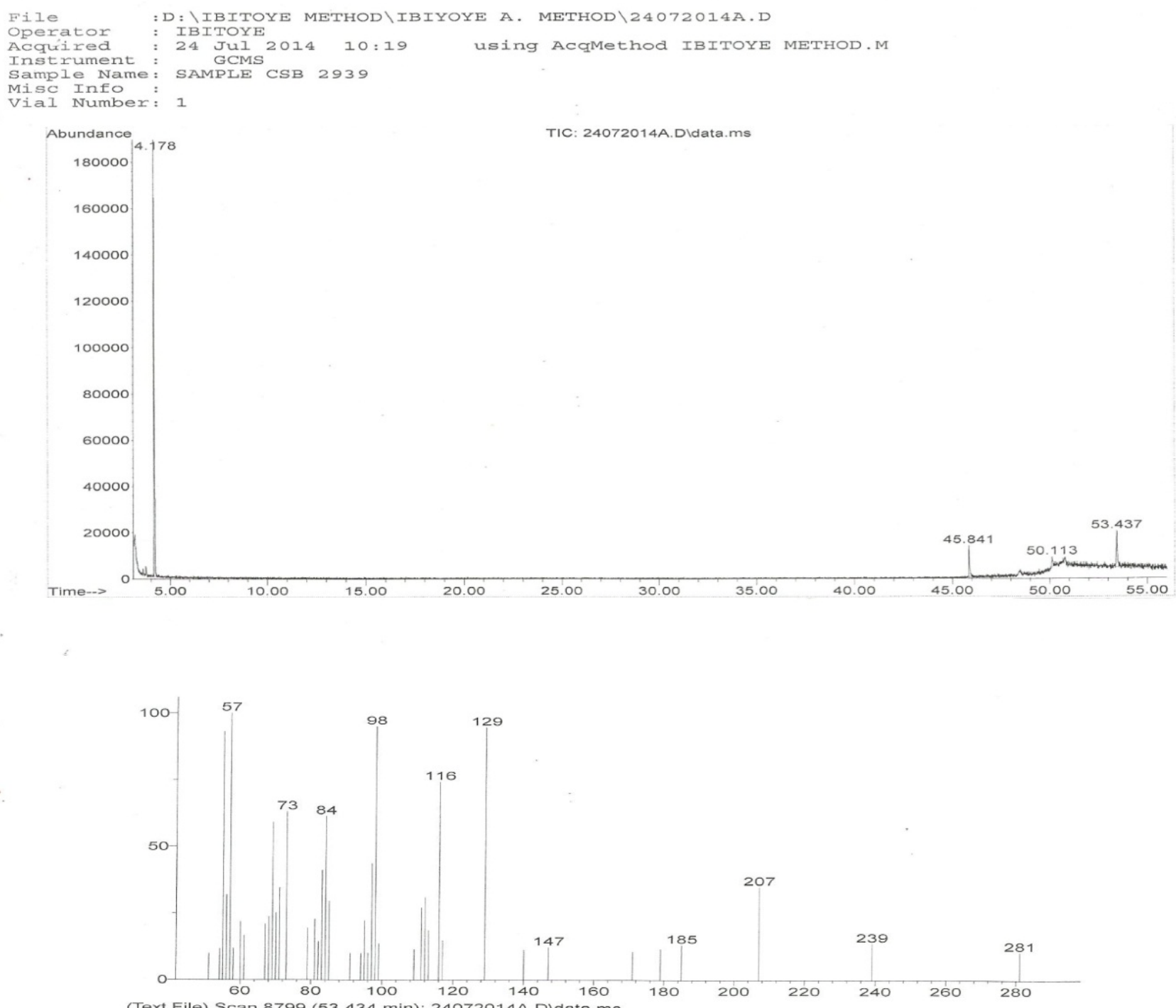

(Text File) Scan 8799 (53.434 min): 24072014 A.Dldata.ms
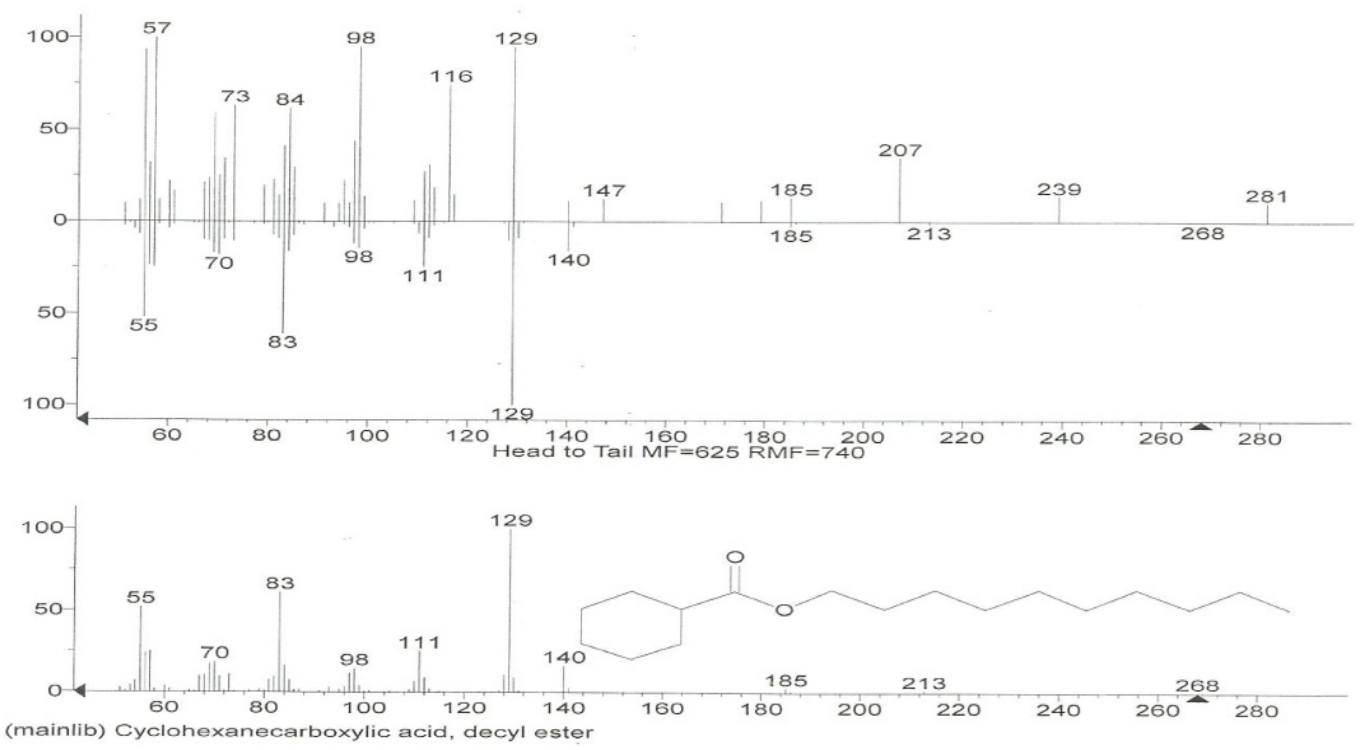

Figure 3: GC-MS Spectrum of F29-39/Z2. 


\section{GC-MS analyses results}

\section{F29-29/Z2}

Three main peaks were highlighted in the GC-MS (Table 2). The 3 major peaks correspond to three different compounds including fatty acids and fatty acid esters. These peaks according to NIST Library matching are cyclohexane carboxylic acid, decyl ester $(51.19 \%$, $\mathrm{RT}=53.434)$ and $\mathrm{n}$-hexadecanoic acid $(34.22 \%, \mathrm{RT}=45.847)$, all constituting $87.65 \%$ of the total.

n-hexadecanoic acid, probably responsible for the yellow color of the isolate [14], has been reported to be among the fatty acids which possess antibacterial and antifungal activity $[15,16]$. It may thus be implicated as part of the agents responsible for the bactericidal activity of the ethanolic extract of $A$. occidentale bark against enterotoxin producing bacteria [4]. It might also be partially or wholly responsible for the antifungal properties exhibited by the ethanolic extract against A. flavus, A. fumigatus, A. niger, curvalaria sp and Fusarium sp [1].

The 17-octadecynoic acid though not a major component of the isolate, has been reported to possess antihypertensive properties [17].

A unique and major component of the isolate proposed by the NIST library of the GC-MS is cyclohexanecarboxylic acid, decyl ester (MF 268). However from the mass spectra (Figure 3), the molecular formula of the matched compound is 281 while its base peak is $\mathrm{m} / \mathrm{z} 129$ which is different from the proposed compound with a base peak of $\mathrm{m} / \mathrm{z} 57$ characteristic of cyclic alcohols. The reason for this could be due to the possible presence of a substituent on the cyclohexane ring which may have been earlier fragmented. The proposed structure for this compound (100) and its fragmentation pattern are given in Figure 4.

\section{F29-39/Z1}

Five compounds were observed in the GC-MS as indicated in Table 3. The MS spectra data in Table 3 showed 5 peaks corresponding to five different compounds. This infers the isolate is a mixture of compounds. The compounds present include 2-trifluoroacetoxydodecane $(22.76 \%$, $\mathrm{RT}=43.032)$, oleic acid $(18.21 \%, \mathrm{RT}=48.199), 1$-cyclohexylnonene (7.03\%, RT=48.365), octadecanoic acid, 2,3-dihydroxypropyl ester $(45.06 \%, \quad \mathrm{RT}=49.052)$ and 3-[(trimethylsilyl)oxy]-17-[o(phenylmethyl)oxime]-(3a,5a)-androstane-11,17-dione (7.0\%, $\mathrm{RT}=53.560)$. 2-trifluoroacetoxydodecane and Octadecanoic acid, 2, 3-dihydroxypropyl ester are the major compounds present as they constitute $67.82 \%$ of the total. 2-trifluoroacetoxydodecane, one of the major constituents has been reported to possess antitumor activity against murine mammary adenocarcinoma [18]. Octadecanoic acid, 2, 3-dihydroxypropyl ester also one of the main components of the isolate, has been reported to possess therapeutic activities which include antioxidant, hepatoprotective, antihistaminic, hypocholesterolemic and antieczemic activities. Its antioxidant activity is possibly evident in the reported antioxidant property of the fatty acid octacosanoic acid [19].

A unique constituent of this isolate is the androstane steroid 3-[(trimethylsilyl) oxy]-17-[o-(phenylmethyl) oxime]-(3a,5a)androstane-11,17-dione. Although it is not a major constituent of the isolate, it is significant because no androstane steroid has been reported to be isolated from any part of Anacardium occidentale as at the time of this report. Furthermore, the structure proposed by the NIST library has been modified due to the low percentage matching between its mass spectra and the compound's mass spectra. The base peak of the library suggestion is $\mathrm{m} / \mathrm{z} 91(\mathrm{MF}=381)$ while that of the matched compound is $\mathrm{m} / \mathrm{z} 207$ $(\mathrm{MF}=341)$, hence the need to modify the structure to obtain a compound whose spectra matches that obtained from the GC-MS (Figure 5).

The structure and fragmentation pattern of the modified androstane steroid proposed are shown in Figure 6. It is a hydroxylimine steroid. It is noteworthy that androstane steroids have been reported to have potentials in: alleviating stress, anxiety, mood disorders, seizures,

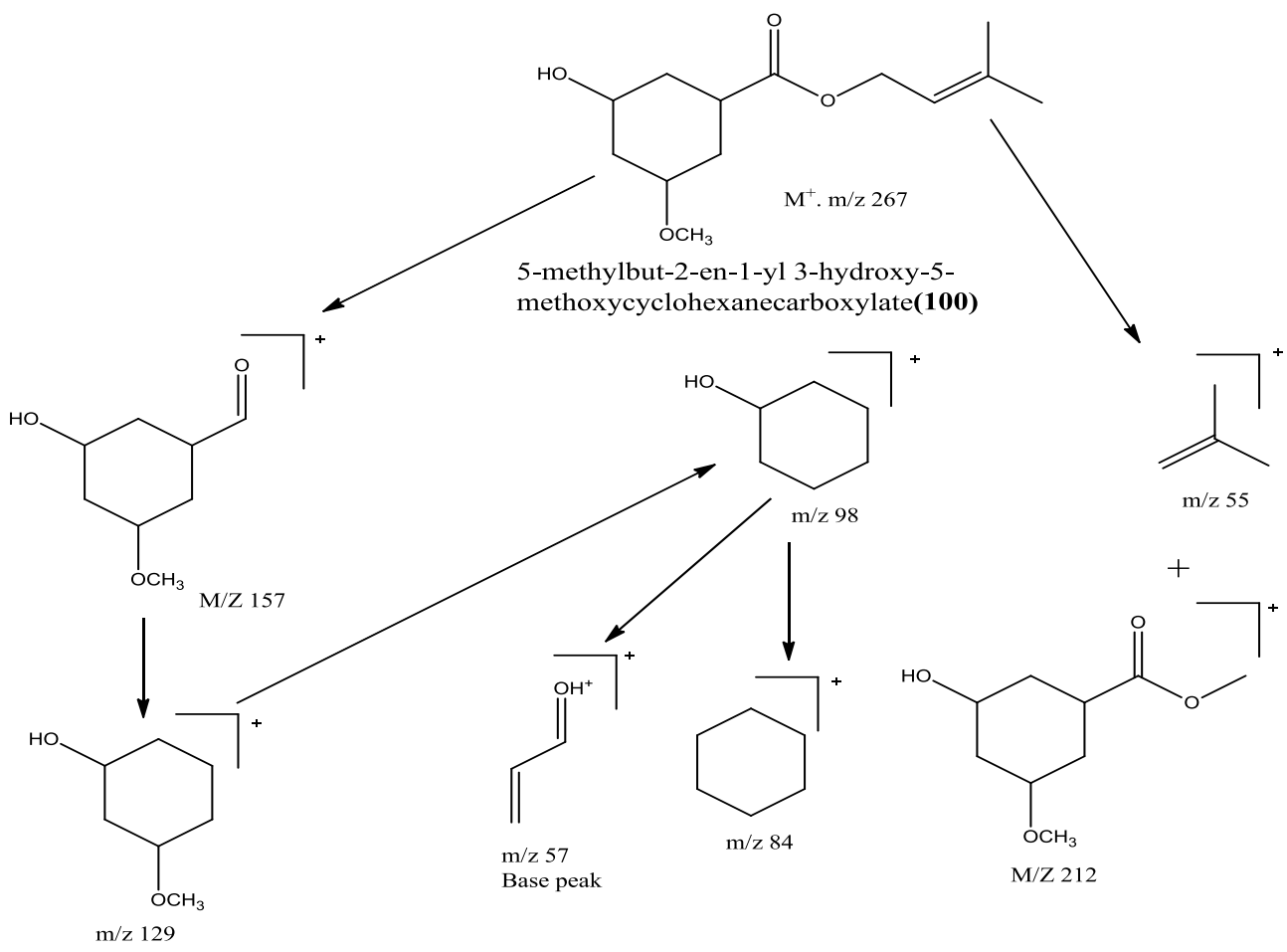

Figure 4: Fragmentation of 5-methylbut-2-en-1-yl 3-hydroxy-5-methoxycyclohexanecarboxylate. 
Citation: Fadeyi OE, Olatunji GA, Ogundele VA (2015) Isolation and Characterization of the Chemical Constituents of Anacardium occidentale Cracked Bark. Nat Prod Chem Res 3: 192. doi:10.4172/2329-6836.1000192

\begin{tabular}{|c|c|c|c|c|}
\hline S/No & Name of Proposed Compound & Ret. Time & $\%$ Composition & Mass spectra data \\
\hline 1. & 2-trifluoroacetoxydodecane & 43.032 & 22.76 & $55,60,69,73,77,84,98,111,116,129,207$ \\
\hline 2. & Oleic acid & 48.199 & 18.21 & $\begin{array}{l}55,69,73,77,81,91,95,109,116,123,129,135,147,165,185,207, \\
221,239,281\end{array}$ \\
\hline 3. & 1-cyclohexylnonene & 48.365 & 7.03 & $55,69,73,83,97,105,129,179,191,207,267,281,341$ \\
\hline 4. & Octadecanoic acid, 2,3-dihydroxypropyl ester & 49.052 & 45.04 & $55,69,84,98,116,129,154,171,185,193,207,267,281,297$ \\
\hline 5. & $\begin{array}{l}\text { 3-[(trimethylsilyl)oxy]-17-[o-(phenyl methyl)oxime]- } \\
\text { (3a,5a)-androstan -11,17-dione }\end{array}$ & 53.560 & 7.0 & $\begin{array}{l}55,69,73,81,97,111,129,147,179,193,207,221,267,281,327 \\
341\end{array}$ \\
\hline
\end{tabular}

Table 3: GC-MS Analysis of F/29-39/Z1.
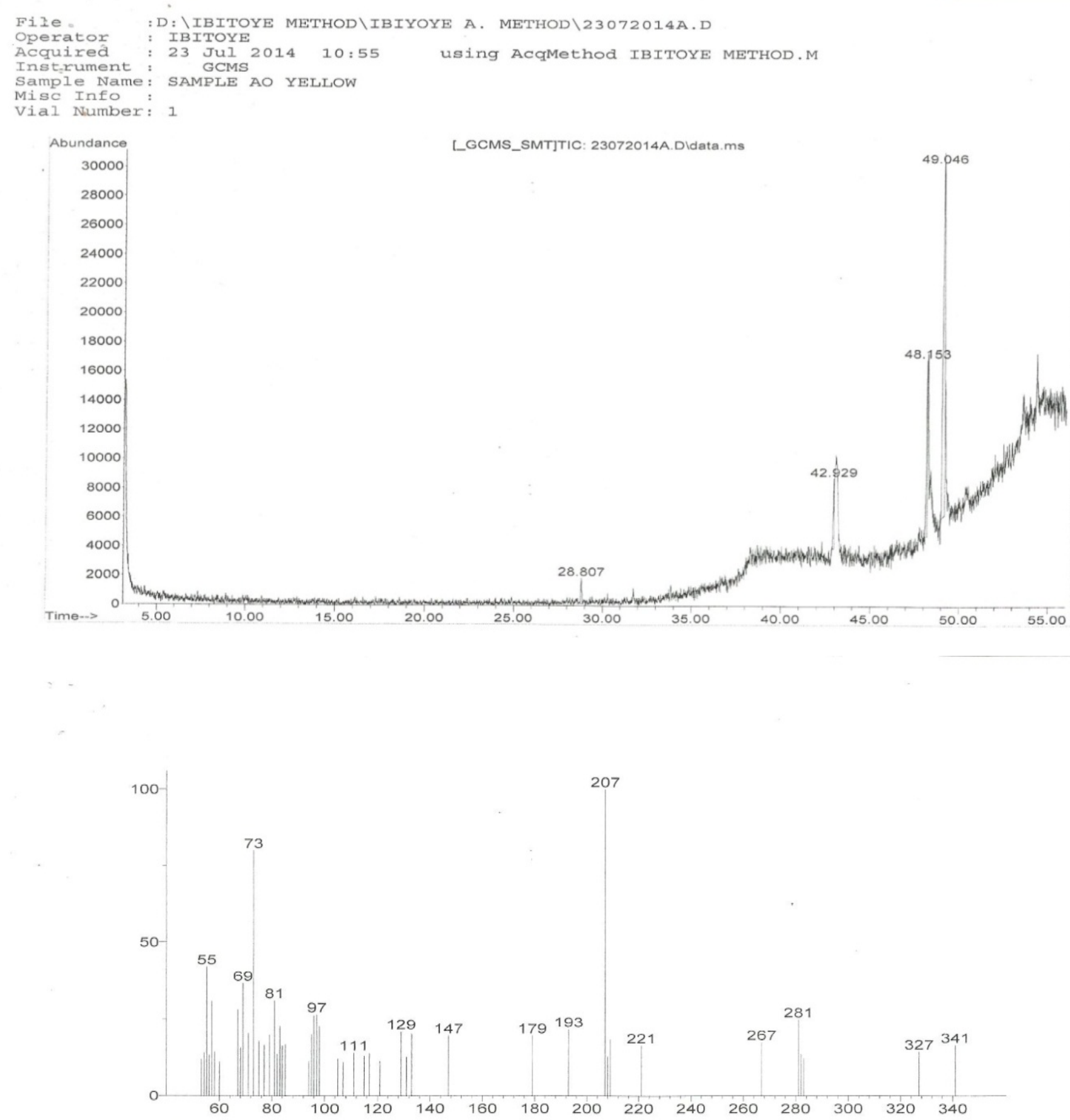

(Text File) Scan 8821 (53.560 min): 23072014 A.Didata.ms 

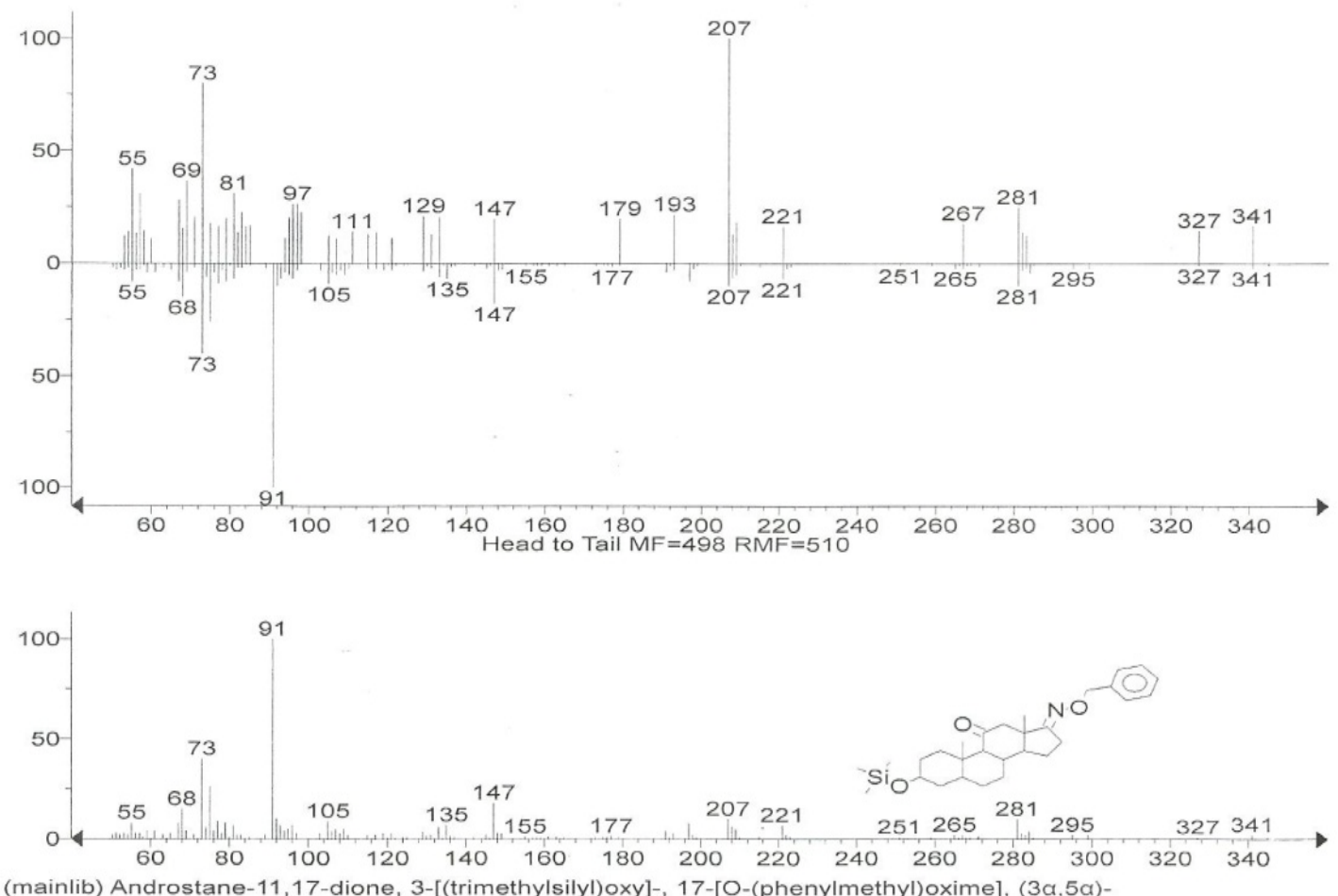

Figure 5: GC-MS Spectrum of F29-39/Z1.

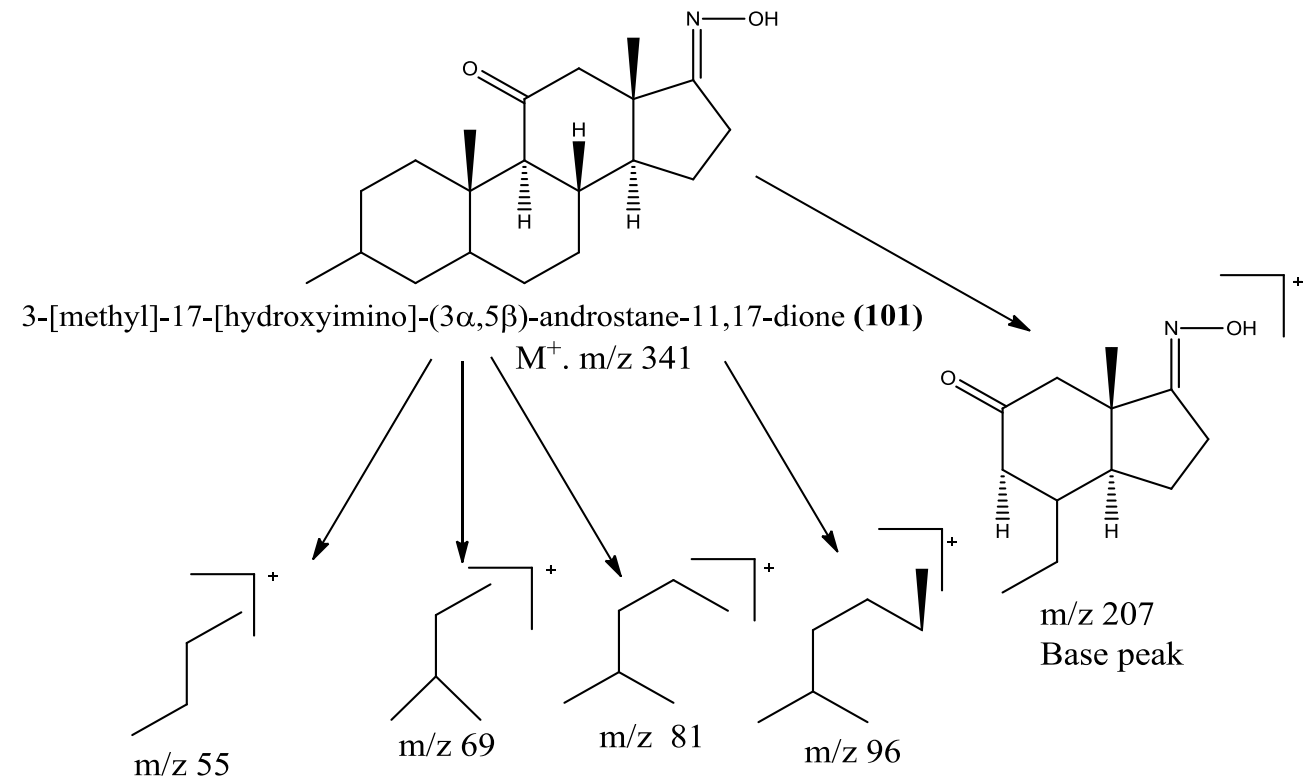

Figure 6: Proposed structure and fragmentation pattern of the modified androstane steroid for isolate F29-39/Z1.

depression; treatment of drug and alcohol abuse, memory, premenstrual disorders, and neural system damage [20].

\section{Conclusion}

The cracked bark of A. occidentale was found to contain of fatty acid esters, the notable one being 5-methylbut-2-en-1-yl 3-hydroxy5 -methoxy cyclohexane carboxylate. Also noteworthy is a unique new and androstane steroid derivative being reported for the first time in Anacardium occidentale. These are compounds which could serve as new lead compounds with promising biological activities.

\section{Acknowledgements}

Department of Chemistry, University of Ilorin; Chemical Research Laboratory, Redeemer's University; Kwara State Teaching Service Commission. 
Citation: Fadeyi OE, Olatunji GA, Ogundele VA (2015) Isolation and Characterization of the Chemical Constituents of Anacardium occidentale Cracked Bark. Nat Prod Chem Res 3: 192. doi:10.4172/2329-6836.1000192

\section{References}

1. Rajesh KV, Sumathi CS, Balasubramanian V, Ramesh N (2009)Elementary chemical Profiling and antifungal properties of cashew (Anacardium occidentale L.) nuts. Botany Research International 2: 253-257.

2. Paramashivappa R, Phain KP, Vithayathil PJ, Rao AS(2001) Method for Isolation of major Phenolic constituents from cashew (Anacardium occidentale L.) nutshell liquid. Journal of Agricultural Food Chemistry 49: 2548-2551.

3. Duke JA (2001) The green pharmacy anti-aging prescriptions: herbs, foods and natural formulas to keep you young. Emmaus, Pennsylvania Rodale Press.

4. Arekemase MO, Oyeyiola GP, Aliyu MB (2011) Antibacterial Activity of Anacaridum Occidentale on Some Enterotoxin Producing Bacteria. International Journal of Biology 3: 92-99.

5. Olatunji LA, Okwusidi JI, Soladoye AO (2005) Antidiabetic Effect of Anacardium occidentale Stem-Bark in Fructose-Diabetic Rats. Pharmaceutical Biology 43 : 589-593.

6. Agedah CE, Bawo DDS, Nyananyo BL (2010) Identification of antimicrobial properties of cashew, Anacardium occidentale L. (Family Anacardiaceae). Journal of Applied Science and Environmental Management 14: 25-27.

7. Terdong LT, Dimo PDD, Dzeufiet AE, Asongalem DS, Sokeng P et al. (2006) An anti-hyperglycemic and renal protective activity of Anacardium occidentale (Anacardiaceae) leaves in streptozotocin. Taxus bakata. Pharmaceutical biology 39: 236-238.

8. Assuncao RB, Mercadante AZ (2003) Carotenoids and ascorbic acid from cashew apple (Anacardium occidentale L.): variety and geographic effects. Food Chemistry 81: 495-502.

9. De Brito SE, Pessanha de Araujo MC, Lin L, Harnly J (2007) Determination of the flavonoid components of cashew apple (Anacardium occidentale) by LCDAD-ESI/MS. Food Chemistry 105: 1112-1118.

10. Terdong L, Madiraju P, Martineau L C, Valler D, Arnason JT et al. (2010) Hydroethanolic extract of cashew tree (Anacardium occidentale) nut and its principa compound, anacardic acid, stimulate glucose uptake in $\mathrm{C} 2 \mathrm{C} 12$ muscle cells. Molecular Nutrition and Food Research 54: 1753-1762.
11. Subramanian SS, Joseph KJ, Nair AGR (1969) Polyphenols from anacardium occidentale. Phytochemisty, Pergamon Press, 8: 673-674.

12. William PJ, Douglas K (2006) Extraction of plant secondary metabolites in natural products isolation. 2nd edn. Humana Press, New Jersey. 20: 323-351.

13. Fazali F, Zulkhiari A, Nurhaizan ME, Kamal NH,Zamree $\mathrm{MS}$, et al Photochemical Screening, In-vitro and in-vivo antioxidant of aqueous extract of anacardium occidentale linn and its effects on endogenous antioxidant enzymes in hyperchloesterolemic induced rabbits. Research Journal of Biological Sciences 6: 69-74.

14. Wang $Y$, Jun $Y$, Yanjiang $Q$, Zhang $H$, Xin Lu (2007) Studies on Antioxidant Activity and Chemical Constituents of Artemisia halodendron. Asian Journal of Traditional Medicine 2: 31-32.

15. McGraw LJ, Jager AK, Van Staden J (2002) Isolation of antibacterial fatty acids from Schotiabrachypetala. Fitoterapia 73: 431-433.

16. Seidel V, Taylor PW (2004) In vitro activity of extracts and constituents of Pelagonium against rapidly growing mycobacteria. International Journal of Antimicrobial Agents 23: 613-619.

17. Evans RG, Day KH, Roman RJ, Hopp KH, Anderson WP (1998) Effects of Intrarenal Infusion of 17-octadecynoic acid on Renal Anti-hypertensive Mechanisms in Anesthetized Rabbits. American Journal of Hypertension 11: 803-812.

18. Sundaram MM, Karthikeyan K, Sudarsanam D, Brindha P (2010) Antimicrobia and Anticancer Studies on Euphorbia Heterophylla. Journal of Pharmacy Research 3: 2332-2333.

19. Ibrahim M, Imram M, Hussain A, Aslam M, Rehmani FS, et al. (2012) Pakistan Journal of Chemistry 2: 24-28.

20. Runyon S P, Rogawski M, Cook E, Kepler J, Navarro H et al. (2014) Androstane and Pregnane Steroids With Potent Allosteric Gaba Recepto Chloride lonophore Modulating Properties. United States Patent Application 20140094619. 